\title{
Role of Common Addictive Habits on Hypovitaminosis D among Bangladeshi People
}

\author{
AHM Habibur Rahman *1, Md. Emdadul Haque ${ }^{2}$, Lubna Naznin ${ }^{3}$, Nasir Uddin Ahmed ${ }^{4}$
}

\section{Abstract}

Introduction: Hypovitaminosis $D$ is a silent but very devastating health issue throughout the world. Some common addictive habits in our country play important role on the issue. The objective of this study was to determine the role of common addictive habits on hypovitaminosis D among the clients attending specialized hospitals. Materials and Methods: This cross-sectional study was conducted among 264 respondents attended Armed Forces Institute of Pathology (AFIP), Dhaka Cantonment for estimation of 25(OH) D within the period of July 2017 to June 2018. Data were collected by face-to-face interview, reviewing with Vitamin $D$ level of the participants from laboratory with the help of a semi-structured questionnaire and checklist respectively. Data were checked, and analyzed with the help of SPSS version 23. Results: Among the respondents, majority $(68.56 \%)$ were female. The mean $\pm S D$ age of the respondents was $48.23 \pm$ 14.05 years. The mean $\pm S D$ level of $25(\mathrm{OH}) \mathrm{D}$ was $50.01 \pm 29.93 \mathrm{nmol} / \mathrm{L}$. Among the males, it was $50.86 \pm 28.61 \mathrm{nmo} / \mathrm{L}$ and $49.60 \pm 26.19 \mathrm{nmol} / \mathrm{L}$ among the female. The proportion hypovitaminosis $D$ was $84.84 \%$ and a mare difference was found among male and female respondents $(84.5 \%$ and $85.5 \%$ respectively. Smokers $(43.88 \pm 13.01 \mathrm{nmol} / \mathrm{L})$ were found with lower level of vitamin $D$ than non-smokers $(50.88 \pm 28.08 \mathrm{nmol} / \mathrm{L})(p<0.05)$. The respondents having habit of chewing betel nut showed lowerlevel of $25(\mathrm{OH}) \mathrm{D}$ than those does not practice that $(51.63 \pm 18.07 \mathrm{Vs} 46.12 \pm 13.01 \mathrm{mmol} / \mathrm{L})$. Conclusion: The proportion of hypovitaminosis $D$ was too high. Effective measure to be taken at all level to overcome the nutritional disorder.

Keywords:25 $(\mathrm{OH})$ D, Smoking, Betel nut, Sun shine.

Number of Tables:04; Number of Figures: 02; Number of References: 19; Number of Correspondences; 04

*1. Corresponding Author:

Lt Col Dr. AHM Habibur Rahman

MBBS, MPH, M Phil

Commanding Officer

CMH Momenshahi Cantonment.

2. Prof. Dr. Md. Emdadul Haque

MBBS, M Phil

Professor

Department of Biochemistry and Nutrition

NIPSOM, Mohakhali, Dhaka.

3. Lt Col Dr. Lubna Naznin

MBBS, FCPS, DCP

Department of Biochemistry

AFIP, Dhaka Cantonment.

\section{Lt Col Dr. Nasir Uddin Ahmed}

MBBS, FCPS

Classified Specialist in Medicine

$\mathrm{CMH}$ Momenshahi Cantonment

\section{Introduction}

Despite of ample amount of sunshine in Bangladesh vitamin $\mathrm{D}$ deficiency is present in a sizeable share of general population which in itself seems to be a paradox $^{1}$. This sub-continent receives a plenty of sunshine all year round and thus people in India should not lack vitamin D. On the contrary, epidemiologic studies from different parts in India reported higher than 70\% prevalence of vitamin D deficiency in all age groups, including toddlers, school children, pregnant women and their neonates and adult males ${ }^{2}$. Leading more of an indoor life due to urbanization underlies one of the causes of such deficiency in children brought up in well off families.

With the advance of development and technological improvement it is fact that life expectancy is increasing day by day. Bangladesh is also achieving that in a higher scale. With the age people are suffering from various physical problem. Issues originated from vitamin D deficiency is also playing serious role in our daily life. Though many of our population are suffering from different types of problem including unusual pain, there are very less study conducted on this topic in Bangladesh. A high prevalence of vitamin D deficiency, low dietary intake of calcium was observed in premenopausal Bangladeshi women of both high and low socioeconomic status. Their lifestyle largely confining them to the home and the traditional clothing that Bangladeshi women wear exposes very little of their skin to sunlight. Under these conditions women in different groups are at risk of developing vitamin D deficiency $^{3}$.

Assessment of vitamin $\mathrm{D}$ is based on measurement of serum $25(\mathrm{OH}) \mathrm{D}$. Vitamin D deficiency is typically defined as circulating $25(\mathrm{OH}) \mathrm{D}$ concentrations less than $20 \mathrm{ng} / \mathrm{mL}(50 \mathrm{nmol} / \mathrm{L})$. In this state, the subsequently low ionized calcium concentration stimulates PTH secretion, which eventually leads to increased $25(\mathrm{OH}) \mathrm{D}$ synthesis ${ }^{4}$. An insufficient exposure to sunlight is a 
major cause of vitamin D deficiency. Other causes are sunscreen sun protection., dark skin, body mass index (BMI) greater than 30, malabsorptive conditions, and use of a wide variety of medications including antiretroviral drugs. Geographic latitude, time of the day for sunlight exposure, seasonal fluctuations and age also determine the vitamin D levels.

\section{Materials and Methods}

A cross sectional study was carried out to identify the sociodemographic determinants of Hypovitaminosis D. A total of 264 young adults were enrolled during July 2017 to June 2018 and were recruited from biochemistry lab of Armed Forces Institute of Pathology (AFIP) Dhaka cantonment. Information on sociodemographic factors including education and income were obtained by self-reported questionnaires. Cut off point of hypovitaminosis D was set as $75 \mathrm{nmol} / \mathrm{L}$. Data were analyzed by SPSS version 23. Statistical tests were done by chi square test, One-way ANOVA and t Test in specific issues.

\section{Food and addictive factors of Hypovitaminosis D}

Common food -Very few foods in nature contain vitamin D. The flesh of fatty fish (such as salmon, tuna, and mackerel) and fish liver oils are among the best sources ${ }^{6}$. Small amounts of vitamin D are found in beef liver, cheese, and egg yolks. Vitamin D in these foods is primarily in the form of vitamin D3 and its metabolite $25(\mathrm{OH}) \mathrm{D} 3^{7}$. Some mushrooms provide vitamin D2 in variable amounts ${ }^{8}$. Mushrooms with enhanced levels of vitamin D2 from being exposed to ultraviolet light under controlled conditions are also available ${ }^{6}$.

Smoking- Several hypotheses have been put forward concerning the mechanisms by which smoking affects bone, the main focus being on the anti estrogenic effect. Smokers are lean ${ }^{9}$, have an early menopause ${ }^{10}$, and have reduced levels of circulating oestrogens due to an increased hepatic turnover ${ }^{11}$. All these factors contribute to a reduced exposure to estrogen, resulting in an increased early bone loss.

Other lifestyle factors are regarded as more prevalent among smokers compared to nonsmokers such as less physical activity, increased alcohol intake, associated nutritional deficiencies, all of which might play a role. A direct toxic effect of tobacco smoking on bone cells is also a possibility ${ }^{12}$. Other hormonal systems, glucocorticoids, pituitary, and thyroid hormones, may be affected by smoking ${ }^{13}$. Parathyroid hormone $(\mathrm{PTH})$ and vitamin D metabolites are crucial in the regulation of calcium homeostasis and bone metabolism. An effect of smoking on PTH or 25-hydroxyvitamin D (25OHD) levels has only been investigated in few studies ${ }^{14}$.

Betel nut-Areca nut has diverse effects on the digestive system and metabolism of food in the human body. It leads to lowering of plasma cholesterol by up to $25 \%$ due to inhibition of intestinal acetyl co-enzyme acyltransferase (ACAT) and pancreatic cholesterol esterase (pACE), resulting in decreased cholesterol absorption ${ }^{15}$. Areca nut users have aggravated effects of Vitamin D deficiency due to the powerful effect of increased expression of $25(\mathrm{OH})$ ase, leading to decreased serum calcitriol as areca nut has an independent effect on $25(\mathrm{OH})$ ase $^{16}$.

\section{Results}

The result was based on a sample of 264 adult persons reported to Armed Forces Institute of Pathology (AFIP) under Dhaka cantonment. The data releted to addictive habits were recorded and then analyzed through SPSS version 23. Table I shows gender and menopausal state of the respondents About gender, $68.56 \%$ were female and rest were male. Among the female respondents 90 $(49.72 \%)$ has developed their menopause and rest 91 (50.28\%) were in reproductive age group.

Table-I: Some demographic data of the respondents.

\begin{tabular}{llll}
\hline Variable & Group & Frequency & Percent \\
\hline Gender & Male & 83 & 31.44 \\
& Female & 181 & 68.56 \\
Menopausal & Menopause & 90 & 49.72 \\
state (F) & Non menopause & 91 & 50.28 \\
\hline
\end{tabular}

\section{Habit of smoking by the respondents}

Among the respondents $241(91.20 \%)$ were nonsmoker and remaining $23(8.80 \%)$ were found smoker (Figure -1 ).

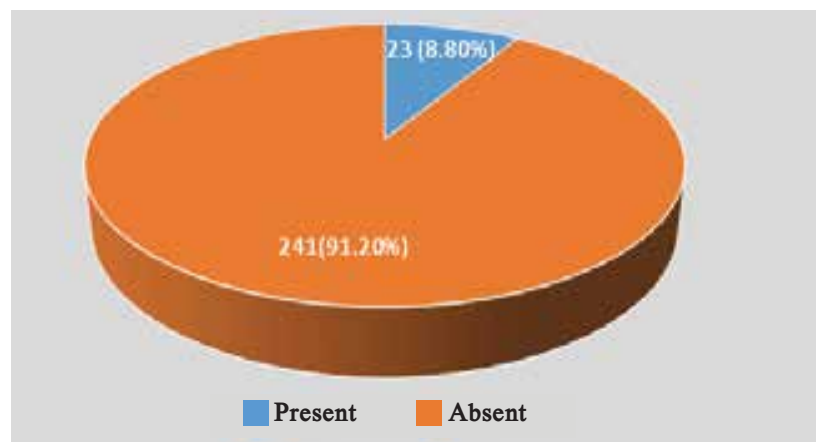

Figure-1: Distribution of respondents by their habit of smoking $(n=264)$.

\section{Habit of chewing betel nut among the respondents}

Among the respondents $231(87.50 \%)$ did not chew betel nut and only $33(12.50 \%)$ had habit of chewing betel nut (Figure-2)

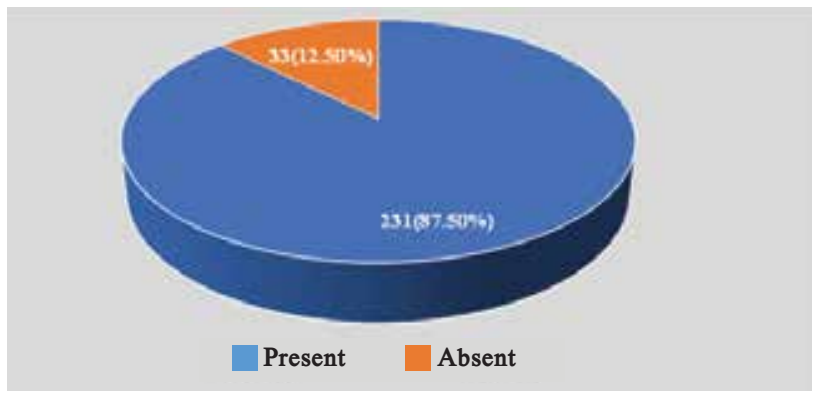

Figure 2: Distribution of the respondents by chewing betel nut $(\mathrm{n}=264)$. 
Table II shows a strong relation between smoking and chance of having

hypovitaminosis D. Among the smokers the proportion of hypovitaminosis D was $91.3 \%$ (21 out of 29 ) and among non-smokers it was $84.1 \%$ (201 out of 239). This association was statistically significant $(\mathrm{p}<0.05)$.

Table-II: Distribution of hypovitaminosis D by habit smoking ( $n=264)$.

\begin{tabular}{llll}
\hline \multicolumn{4}{c}{$\begin{array}{c}\text { Presence of } \\
\text { hypovitaminosis D }\end{array}$} \\
State of smoking & \multicolumn{1}{c}{ Present } & \multicolumn{1}{c}{ Absent } & Test of significance \\
\hline Smoking & $21(9.38 \%)$ & $2(10.0 \%)$ & $\chi^{2}=4.521$ \\
Not smoking & $203(90.62 \%)$ & $38(90.0 \%)$ & $\mathrm{df}=1$ \\
Total & $224(100.0 \%)$ & $40(100.0 \%)$ & $\mathrm{p}=0.019$ \\
\hline
\end{tabular}

Table III shows a strong relation between taking of betel nut and chance of having hypovitaminosis D. Among those who did not take betel nut their hypovitaminosis D level was $83.5 \%$ (193 out of 231). But the persons who used to take betel nut at any amount their proportion was $93.9 \%$ (31 out of 33). Those were mainly female populations. This association was statistically significant $(\mathrm{p}<0.01)$.

Table-III: Distribution of hypovitaminosis D by habit of chewing betel nut $(n=264)$.

\begin{tabular}{llll}
\hline & \multicolumn{3}{c}{ Presence of hypovitaminosis D } \\
$\begin{array}{l}\text { Chewing } \\
\text { betel nut }\end{array}$ & \multicolumn{1}{c}{ Present } & \multicolumn{1}{c}{ Absent } & Test of significance \\
\hline Yes & $31(13.84 \%)$ & $2(5.0 \%)$ & $\chi^{2}=6.769$ \\
No & $193(86.16 \%)$ & $38(95.0 \%)$ & $\mathrm{df}=1$ \\
Total & $224(100.0) \%$ & $40(100.0 \%)$ & $\mathrm{p}=0.003$ \\
\hline
\end{tabular}

Table IV shows that the mean level of vitamin was clearly different between two groups of same variable. Respondents bearing habit of chewing betel nut showing less vitamin D than those who do not chew that. Mean vitamin D level was lower among the smoker than that of non-smokers.

Table- IV: Relation of addictive habit with mean vitamin D level $(n=264)$.

\begin{tabular}{llllll}
\hline Variable & & $\begin{array}{l}\text { Frequency } \\
(\%)\end{array}$ & $\begin{array}{l}\text { Mean+ SD vit D } \\
(\mathrm{nmol} / \mathrm{L})\end{array}$ & $\begin{array}{l}\mathrm{t} \text { Score } \\
\mathrm{p} \text { Value }\end{array}$ \\
\hline Habit of chewing betel nut & Present & $33(12.5 \%)$ & $44.12 \pm 13.01$ & -2.519 & 0.012 \\
& Absent & $231(87.5 \%)$ & $51.63 \pm 28.07$ & & \\
Habit of smoking & Present & $23(8.71 \%)$ & $43.88 \pm 13.01$ & -1.977 & 0.049 \\
& Absent & $241(91.29 \%)$ & $50.88 \pm 28.08$ & & \\
\hline
\end{tabular}

\section{Discussion}

The present study found $23(8.71 \%)$ as smoker. Among the smokers the proportion of hypovitaminosis D was $91.30 \%$ (21 out of 23) and among the non-smokers the proportion was 84.23 (203 out of 241).
Regarding mean value of vitamin D among two groups, there was some differences in serum $25(\mathrm{OH}) \mathrm{D}$ level. The mean \pm SD level of $25(\mathrm{OH}) \mathrm{D}$ among the smokers was $46.23+13.11 \mathrm{nmol} / \mathrm{L}$ and that of non-smokers was $51.02+$ $18.88 \mathrm{nmol} / \mathrm{L}(\mathrm{t}, \mathrm{p}<0.05)^{17}$ by their study in Athens recommended that smokers had a significantly higher risk of vitamin D deficiency. A cross sectional study was carried out in Copenhagen from June 2012 to May 2014 on sociodemographic determinants of hypovitaminosis D. It was revealed that smoking was associated with higher $\mathrm{RR}=1.33(1.02,1.73)$ for vitamin $\mathrm{D}$ deficiency/insufficiency compared with non-smokers ${ }^{18}$.

In this study 33 respondents were found having practice of chewing betel nut. Among those proportion of hypovitaminosis D was remarkably high. The study shows a strong relation between taking of betel nut and chance of having hypovitaminosis $\mathrm{D}$. Among those who did not take betel nut their hypovitaminosis D level was $83.5 \%$. But the persons who used to take betel nut at any amount their proportion was $93.9 \%$. They were mainly female populations. This association was statistically significant $(p<0.01)$. More previous studies have suggested that chewing betel nut may aggravate vitamin D deficiency ${ }^{19}$, since compounds present in betel nut may increase expression of the enzyme 24-hydroxylase, which catalyzes conversion of $1,25(\mathrm{OH})_{2}$ vitamin $\mathrm{D}$ to the relatively inactive 24, $25(\mathrm{OH})_{2}$ vitamin D.

\section{Conclusion}

Smoking and Areca nut are the addictive substance consumed in many parts of the world by people of all the age groups also not so uncommon among the people of Bangladesh. Apart from being carcinogenic to the oral cavity, pharynx, esophagus, liver and uterus, it has many diverse effects on the human body affecting almost all the organs. Women who consume areca nut regularly have more incidences of low birth weight and preterm deliveries. Thus, it is evident that these two addictive habits are harmful and affects the whole human body, and its use must be tightly regulated for the welfare of the society.

\section{Conflict of Interests: None.}

\section{Acknowledgement}

The author respectfully thanks to Professor Md Emdadul, MBBS, M Phil who guided him in thesis work throughout the time. Lt Col Lubna Naznin, MBBS, FCPS, DCP of AFIP, Dhaka Cantonment helped a lot regarding laboratory report of $25(\mathrm{OH}) \mathrm{D}$ level and guiding him in various aspects.

\section{References}

1. Harinarayan, C.V., Joshi, S.R. Vitamin D status in India. Its implications and remedial measures. J Assoc Physicians India. 2009; 57: 40-48.

2. Babu, U.S., Calvo, M.S. Modern India and the vitamin D dilemma: evidence for the need of a national food fortification program. MolNutr Food Res. 2010; 54: 1134-47. 
https://doi.org/10.1002/mnfr.200900480

\section{PMid:20440690}

3. Islam, M.Z., Lamberg-Allardt, C., Karkkainen, M. Vitamin D deficiency: a concern in premenopausal Bangladeshi women of two socio-economic groups in rural and urban region. Eur J ClinNutr. 2002; 56: 51-56.

https://doi.org/10.1038/sj.ejcn.1601284

PMid: 11840180

4. Brehm, J.M., Schuemann, B., Fuhlbrigge, A.L. Serum vitamin $\mathrm{D}$ levels and severe asthma exacerbations in the Childhood Asthma Management Program study. J Allergy ClinImmunol. 2010; 126(52): 8.

https://doi.org/10.1016/j.jaci.2010.03.043

PMid:20538327 PMCid:PMC2902692

5. Lenders, C.M., Feldman, H.A., Von Scheven, E. Relation of body fat indexes to vitamin D status and deficiency among obese adolescents. American Journal of Clinical Nutrition. 2009; 90(3): 459-67.

https://doi.org/10.3945/ajcn.2008.27275

PMid:19640956 PMCid:PMC2728638

6. U.S. Department of Agriculture, Agricultural Research Service. (2011). USDA

National Nutrient Database for Standard Reference, Release 24. Nutrient

Data Laboratory,[Online] Available at: http://www.ars.usda.gov/ba/bhnrc/ndl. [Accessedon 24 March 2018]

7. Ovesen, L., Brot, C., Jakobsen, J. Food contents and biological activity of 25- hydroxyvitamin D: a vitamin D metabolite to be reckoned with? Ann Nutr Metab. 2003; 47: 107-13.

https://doi.org/10.1159/000070031

PMid: 12743460

8. Mattila, P.H., Piironen, V.I., Uusi-Rauva, E.J., et al. Vitamin D contents in edible mushrooms. J Agric Food Chem. 1994; 42: 2449- 53.

https://doi.org/10.1021/jf00047a016

9. Wack, J.T., Rodin, J. Smoking and its effects on body weight and systems of calorie regulation. Am. J. Clin. Nutr. 1982; 35: 366-380.

https://doi.org/10.1093/ajcn/35.2.366

PMid:7039293

10. Jick, H., Porter, J., Morrison, A.S. Relation between smoking and age of natural menopause. Lancet. 1977; 1: 1354-1355.

https://doi.org/10.1016/S0140-6736(77)92562-4
11. Daniel, M., Martin, A.D. Drink water, D.T. Cigarette smoking, steroid hormones, and bone mineral density in young women. Calcif. Tissue Int. 1992; 50: 300-305.

https://doi.org/10.1007/BF00301626

12. Fang, M.A., Frost, P.J., Lida-Klein., A., et al. Effects of nicotine on cellular function in UMR 106-01 osteoblast-like cells. Bone. 1991; 12: 283-286.

https://doi.org/10.1016/8756-3282(91)90077-V

13. Fisher, C.L., Mannino, D.M., Herman, W.H., et al. Cigarette smoking and thyroid hormone levels in males. Int. J. Epidemiol. 1997; 26: 972-977.

https://doi.org/10.1093/ije/26.5.972

PMid:9363517

14. Landin-Wilhelmsen, K., Wilhelmsen, L., Lappas, G., et al. Serum intact parathyroid hormone in a random population sample of men and women: relationship to anthropometry, life- style factors, blood pressure, and vitamin D. Calcif. Tissue Int. 1995; 56: 104-108.

https://doi.org/10.1007/BF00296339

15. Park YB, Jeon SM, Byun SJ, Kim HS, Choi MS. Absorption of intestinal free cholesterol is lowered by supplementation of Areca catechu L. extracts in rats. Life Sci. 2002; 70:1849-59.

https://doi.org/10.1016/S0024-3205(02)01485-6

16. Wu PF, Chiang TA, Chen MT, Lee CP, Chen PH, Ko $\mathrm{AM}$, et al. A characterization of the antioxidant enzyme activity and reproductive toxicity in male rats following sub-chronic exposure to areca nut extracts. J Hazard Mater. 2010; 178: 541-6.

https://doi.org/10.1016/j.jhazmat.2010.01.118

PMid:20202746

17. Kassi, E.N., Stavropoulos, S., Kokkoris, P., et al. Smoking is a significant determinant of low serum vitamin $\mathrm{D}$ in young and middle-aged healthy males. Hormones(Athens). 2014; 14: 245-50.

https://doi.org/10.14310/horm.2002.1521

PMid:25402376

18. Sambrook, P.N., Cameron, I.D., Cumming, R.G. Vitamin D deficiency is common in frail institutionalised older people in northern Sydney. Med J Aust 2002; 176: 560 .

19. Ogunkolade, W.B., Boucher, B.J., Bustin, S.A., et al. Vitamin D metabolism in peripheral blood mononuclear cells is influenced by chewing "betel nut" (Areca catechu) in vitamin D status. J ClinEndocrMetab. 2006; 91(7): 2612--2617.

https://doi.org/10.1210/jc. 2005-2750

PMid:16670168 